\title{
An integrated view of suppressor T cell subsets in immunoregulation
}

\author{
Hong Jiang and Leonard Chess \\ Department of Medicine and Pathology, Columbia University College of Physicians and Surgeons, New York, New York, USA.
}

The immune system evolved to protect organisms from a virtually infinite variety of disease-causing agents but to avoid harmful responses to self. Because immune protective mechanisms include the elaboration of potent inflammatory molecules, antibodies, and killer cell activation - which together can not only destroy invading microorganisms, pathogenic autoreactive cells, and tumors, but also mortally injure normal cells - the immune system is inherently a "double-edged sword" and must be tightly regulated. Immune response regulation includes homeostatic mechanisms intrinsic to the activation and differentiation of antigen-triggered immunocompetent cells and extrinsic mechanisms mediated by suppressor cells. This review series will focus on recent advances indicating that distinct subsets of regulatory $\mathrm{CD4}^{+}$and $\mathrm{CD8}^{+} \mathrm{T}$ cells as well as $\mathrm{NK} \mathrm{T}$ cells control the outgrowth of potentially pathogenic antigen-reactive $\mathrm{T}$ cells and will highlight the evidence that these suppressor $\mathrm{T}$ cells may play potentially important clinical roles in preventing and treating immune-mediated disease. Here we provide a historical overview of suppressor cells and the experimental basis for the existence of functionally and phenotypically distinct suppressor subsets. Finally, we will speculate on how the distinct suppressor cell subsets may function in concert to regulate immune responses.

The potential capacity for the immune response to induce or activate disease was clearly recognized at the turn of the 20th century by Paul Ehrlich, who emphasized that the immune system must carefully distinguish between self and non-self in order to avoid autoimmunity. Ehrlich envisioned that during the ontogeny and outgrowth of the immunocompetent clones responsive to foreign antigens, there had to be mechanisms to control the outgrowth of clones reactive with self (1). Moreover, the failure to control the outgrowth of autoreactive cells would lead to a state of "horror autotoxicus," or autoimmunity. Ehrlich's ideas were amplified and developed with the elaboration of the clonal selection hypothesis (2-4). This hypothesis was further refined with identification of the antigen receptors on $\mathrm{T}$ and $\mathrm{B}$ cells and discovery that the antigen specificity of these receptors is a consequence of random recombination of the many $\mathrm{V}, \mathrm{D}$, and $\mathrm{J}$ genes encoding the antigenbinding sites of these receptors, a process that could generate more than $10^{9}$ distinct receptors (5).

According to a modern interpretation of the clonal selection hypothesis, multiple clones of immunocompetent cells displaying unique antigen-specific receptors exist prior to interaction with antigens and in the case of T cells get selected on the basis of interaction with self-peptides bound to MHC molecules in the thymus. The majority of thymocytes bearing high-affinity receptors for self-antigens are eliminated centrally during thymic differentiation by an apoptotic mechanism termed negative selection. However, many self-reactive $T$ cells with low to intermediate affinity for self-antigen escape thymic negative selection and are released into the periphery, where they are capable of autoantigen-driv-

Nonstandard abbreviations used: AICD, activation-induced cell death; CD40L, CD40 ligand; EAE, experimental autoimmune encephalomyelitis; $\alpha$-GalCer, $\alpha$-galactosylceramide; ILT3, Ig-like transcript 3; IPEX syndrome, immunodysregulation, polyendocrinopathy, enteropathy, X-linked syndrome; MBP, myelin basic protein; NKT cells, NK T cells; PLP, proteolipid protein; T1D, type 1 diabetes.

Conflict of interest: The authors have declared that no conflict of interest exists.

Citation for this article: J. Clin. Invest. 114:1198-1208 (2004).

doi:10.1172/JCI200423411. en activation, proliferation, and differentiation into potentially pathogenic effector cells (6-9). Thus, mechanisms that normally regulate the outgrowth or function of these self-reactive $\mathrm{T}$ cells ultimately control the initiation and progression of autoimmune disease. A corollary of these notions is that autoimmune diseases arise from either the failure to eliminate or inactivate high-affinity immunocompetent cells during their ontogeny and/or the failure of the immune system to control the outgrowth or function of intermediate self-reactive clones that escape into the periphery.

In addition to direct autoimmune attack, the immune system can also induce disease, because the very protective immunologic mechanisms that are employed to limit the outgrowth of invading foreign pathogens or tumor cells can induce "collateral damage" on normal, uninfected cells in the vicinity of immune attack. This collateral damage is mediated in large part by inflammatory cytokines and is thought to account for the destruction of normal tissues clinically observed during the physiologic immune attack aimed at the elimination of foreign pathogens or tumors. To prevent immune disease either induced directly by autoimmune attack or to control collateral damage occurring during all immune responses, a complex network of interacting regulatory peripheral mechanisms has coevolved to prevent or dampen immune-mediated diseases. These regulatory systems include mechanisms intrinsic to the antigen activation and differentiation of T cells as well as those mediated by regulatory "suppressor" T cells. This JCI review series on regulatory $\mathrm{T}$ cells will focus on recent advances indicating that distinct subsets of regulatory $\mathrm{CD}^{+}(10-12)$ and $\mathrm{CD}^{+} \mathrm{T}$ cells (refs. 13, 14 and the present article) as well as NK T cells (NKT cells) (15) function to suppress the outgrowth of potentially pathogenic antigen-reactive $\mathrm{T}$ cells. The series will highlight the resurrection of the idea that suppressor $\mathrm{T}$ cells play potentially important clinical roles in the prevention and treatment of immune-mediated disease. The articles will review evidence that suppressor cells are essential for the control of autoimmunity and are also involved in the control of the immune response to transplanted allografts (12), allergens (16), and infectious pathogens. The series will also 


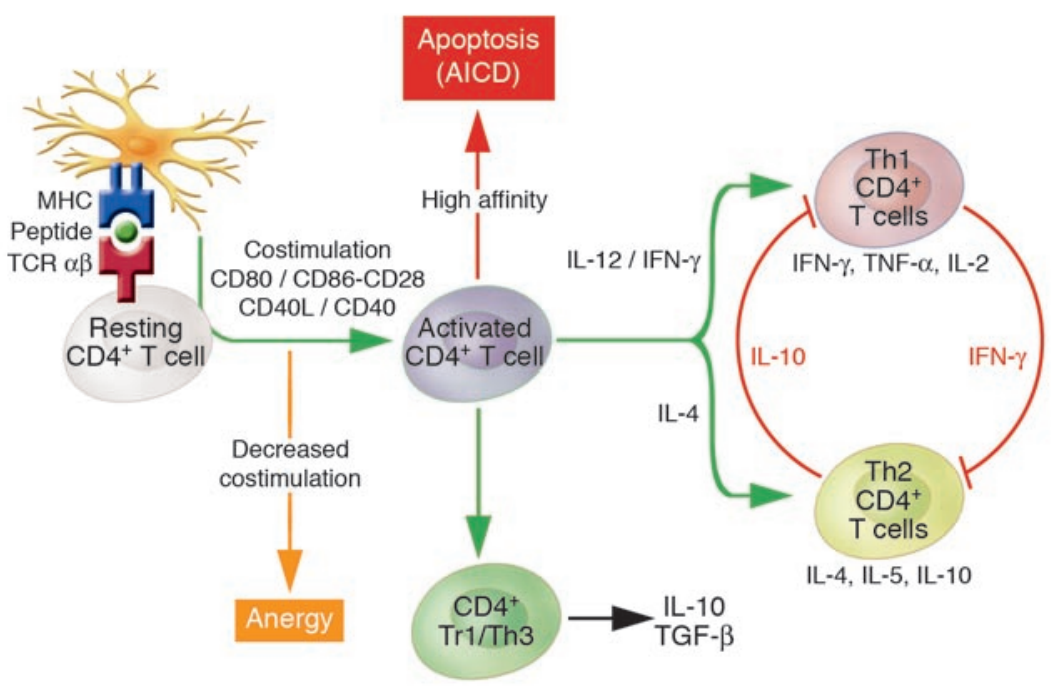

\section{Figure 1}

Homeostatic control of the outgrowth of antigen-activated $\mathrm{CD} 4{ }^{+} \mathrm{T}$ cells. Control of the peripheral immunity is accomplished by mechanisms intrinsic to antigen activation of $\mathrm{CD} 4^{+} \mathrm{T}$ cells; including apoptosis, induction of anergy, and differentiation into Th subsets that are independent of other types of regulatory cells. In addition, superimposed on these intrinsic mechanisms are control mechanisms mediated by distinct subsets of $\mathrm{NKT}, \mathrm{CD}^{+}$, and $\mathrm{CD} 8^{+}$regulatory (suppressor) T cells. include a review of $\mathrm{T}$ cell vaccination, which may be mediated by some or all of the Tregs (17).

In this series introductory article, we will emphasize that the regulation mediated by these suppressor $T$ cell subsets is superimposed on intrinsic regulatory mechanisms induced by antigen activation alone. Thus, we will first describe the intrinsic homeostatic mechanisms that control immune responses independent of suppressor cells. We will then briefly describe the experimental historical basis for the existence of the $\mathrm{CD}^{+}, \mathrm{CD}^{+}$, and NKT suppressor subsets and attempt to give an overview of their unique functions. Finally, as a prelude to the rest of the articles in the series, we will speculate on how the distinct subsets of suppressor cells function in concert to regulate immune responses.

\section{Homeostatic regulatory mechanisms intrinsic to antigen activation and differentiation that function independently of suppressor cells}

TCR affinity, apoptosis, and antigen-induced cell death. Immune responses are initiated when the antigen-specific TCRs expressed by resting $\mathrm{CD}^{+} \mathrm{T}$ cells are triggered by MHC-peptide complexes in concert with costimulatory molecules expressed by APCs (18$20)$. This triggering induces $\mathrm{CD} 4^{+} \mathrm{T}$ cells to proliferate, secrete cytokines, and express cell-surface molecules including the IL-2 receptor (CD25), CTLA-4, and CD40 ligand (CD40L) critical for the subsequent growth and functional differentiation of $\mathrm{T}$ cells. To regulate the immune response, the immune system has also evolved several homeostatic feedback mechanisms to downregulate and control the outgrowth, differentiation, and function of peripheral antigen-activated $\mathrm{CD}^{+} \mathrm{T}$ cells (Figure 1). One level of control resides at the initial clonal activation of the $\mathrm{T}$ cell receptor itself by MHC-peptide complexes. The functional consequences of $\mathrm{T}$ cell signaling are dependent on the affinity and duration of binding of the TCRs with MHC-peptide complexes $(21,22)$. For example, there is a threshold of affinity necessary for optimal activation and differentiation of T cells, whereas triggering of very high-affinity TCRs can induce apoptotic pathways leading to activation-induced cell death (AICD) (23).

The homeostatic role of costimulatory molecules in immunoregulation. During the initial T cell-MHC-peptide interaction, other receptor ligand interactions also become pivotal in ultimately dictating the functional fate of T cells. For example, one of the earliest antigen activation-induced cell-surface molecules expressed by $\mathrm{T}$ cells is CD40L (24). CD40L interacts with CD40 expressed on $B$ cells to induce antibody formation and with CD40 expressed on antigen-presenting DCs to induce cellular immune responses $(25,26)$. Another critical consequence of the interaction of CD $40 \mathrm{~L}$ with CD40 expressed on APCs is the upregulation of other key costimulatory molecules, including CD80 (B71) and CD86 (B72) $(27,28)$. These molecules interact with CD28 expressed on naive $\mathrm{T}$ cells to provide the costimulatory signal required for optimal activation of T cells. However, following activation, a structurally related molecule termed CD152 or CTLA- 4 is expressed that also binds CD80 and CD86 but delivers inhibitory signals to T cells. The consequence of CTLA-4 negative signaling is abrogation of functional activation. The resulting nonfunctional $\mathrm{T}$ cells are termed anergic or tolerant. Thus, blockade of either the CD40L/ CD40 pathway or the CD28/B7 pathway can lead to inhibition of immune responses and tolerance induction (20,28-30).

The differentiation of $\mathrm{CD}^{+} \mathrm{T}$ cells into subsets expressing different arrays of cytokines. A third general set of regulatory mechanisms, also a consequence of the initial triggering of $\mathrm{CD}^{+} \mathrm{T}$ cells by MHC-peptide complexes, is the further differentiation of the $\mathrm{CD}^{+} \mathrm{T}$ cells into the functionally distinct Th1 and Th2 subsets phenotypically distinguished, in part, by the elaboration of distinct sets of cytokines (31-33). In this regard, IFN- $\gamma$ secreted by Th1 cells is known to downregulate the differentiation and function of TH2 cells and, conversely, IL-4. TGF- $\beta$ and IL-10 inhibit Th1 cell differentiation (33-35). In addition, other cytokine-secreting Th subsets capable of secreting the immunosuppressive cytokines IL-10 and/or TGF- $\beta$ but not IL-4 (termed Tr1 or Th3 cells) (36-38) have been observed and will be reviewed in detail in several articles in this review series. A widely prevalent view is that the balance between the emergence of Th1, Th2, as well as the other Th cytokine-secreting CD4 ${ }^{+}$Tregs following antigen activation plays a major role in the outgrowth and functions of self-reactive and foreign reactive clones (39-41).

\section{Homeostatic regulatory mechanisms mediated by dominant suppression of the immune response}

The origin of the idea of suppressor $T$ cells and its initial demise. Superimposed on the intrinsic mechanisms of homeostatic regulation are extrinsic mechanisms mediated by suppressor $T$ cells that control the induction and/or outgrowth of antigen-activated T cells. In 
this regard, the idea that suppressor T cells may be critical to the control of virtually all immune responses arose in the laboratory of Richard Gershon at Yale University in the late 1960s in studies of immune tolerance to foreign antigens. Gershon showed initially that adoptive transfer of $T$ cells from animals made tolerant to foreign antigen " $X$ " could specifically suppress the production of anti$X$ antibodies in recipient animals $(42,43)$. These studies were rapidly extended in numerous laboratories, which documented that suppressor cells were not only involved in the peripheral regulation of cells responding to foreign antigens but also participated in the regulation of self-reactive cells and in the control of autoimmunity $(44,45)$. The first models of the pathways by which suppressor $\mathrm{T}$ cells might function in the specific regulation of immunity arose from the seminal studies by Cantor and Boyse, who showed that genetically well-defined alloantisera could be used to identify phenotypically stable and functionally distinct subsets of $\mathrm{T}$ cells. These studies ultimately led to the discovery of $\mathrm{CD} 4^{+}$and $\mathrm{CD}^{+} \mathrm{T}$ cell subsets (46-50). Implicit in these discoveries was the idea that the $\mathrm{CD}^{+}$and $\mathrm{CD}^{+} \mathrm{T}$ cell subsets were genetically programmed during ontogeny, prior to interaction with antigen, to mediate distinct functional programs. The $\mathrm{CD}^{+} \mathrm{T}$ cells were functionally programmed to induce both antibody responses and cell-mediated immune reactions. In contrast, the $\mathrm{CD}^{+} \mathrm{T}$ cells were not genetically programmed as inducer cells but instead were programmed to differentiate into killer cells capable of destroying tumor cells or cells infected with intracellular pathogens. However, following interaction with antigen-activated $\mathrm{CD} 4^{+} \mathrm{T}$ cells, $\mathrm{CD} 8^{+} \mathrm{T}$ cells could be induced in vitro to differentiate into suppressor cells, which in turn downregulate the activity of the $\mathrm{CD} 4^{+} \mathrm{T}$ cell population $(51$, 52). Experiments employing allosera to the MHC molecule Qa-1 suggested that Qa-1 was expressed on the suppressor-inducer subset of $\mathrm{CD}^{+} \mathrm{T}$ cells $(51,52)$. This is of interest because eventually Qa-1 was cloned and found to be an MHC class Ib molecule capable of presenting endogenous as well as exogenous peptides (53) to $\mathrm{CD}^{+} \mathrm{T}$ cells. However, the potential significance of Qa-1 expression on suppressor-inducer cells in vivo was not delineated until the last several years, with experiments employing monoclonal antibodies to Qa-1 and Qa-1-knockout mice (54-56) (see below). Precise characterization of the specificity and functional phenotype of suppressor cells generated in these complex cellular experiments was impossible, largely because there were no phenotypic markers at the time that definitively distinguished the CD8 suppressor cells from the more conventional CD8 or CD4 T cells. Moreover, the biological significance of these in vitro findings was not placed on firm in vivo footing because of the lack of monoclonal antibodies to the murine CD4 and CD8 populations and the lack of molecular genetics-based approaches to study CD4- or CD8-deficient animals.

In this regard, it is important to emphasize that the original suppressor cell circuits were initially conceived and/or deduced at a time when molecular immunology was in its infancy. For example, the nature of the TCR was unknown, as was the precise structure and function of MHC molecules in restricting T cell activity. In addition, the great majority of the cytokines that are now known to regulate immune functions had not yet been identified. It was also unknown that antigen activation of the TCRs induced intrinsic homeostatic mechanisms, including the differentiation of $\mathrm{CD}^{+}{ }^{+} \mathrm{T}$ cells into Th1 and Th2 subsets which elaborated distinct sets of regulatory cytokines. Clearly, understanding the precise role of these lymphokines in suppression would have significantly influenced the interpretation of data suggesting that an array of antigen-specific factors was uniquely secreted by suppressor cells. Lack of this information, however, caused interest in the models of $\mathrm{T}$ cell suppression mediated by $\mathrm{CD} 8^{+} \mathrm{T}$ cells to wane by the mid-1980s $(45,57,58)$, and skepticism about the importance of T cell suppression dominated the field until the 1990s. Although some of the skepticism concerning $T$ cell suppression mediated by $\mathrm{CD}^{+} \mathrm{T}$ cells in the mid-1980s was justified, it is clear now that the proverbial baby had been thrown out with the bath water. Indeed, many of the ideas and models of immunoregulation that have been dismissed were essentially correct and have far reaching biological and clinical significance.

The resurrection of $C D 8^{+}$suppressor $T$ cells. The resurrection of the concept that $\mathrm{CD}^{+} \mathrm{T}$ cells mediate $\mathrm{T}$ cell suppression was initiated, in part, by the publication of 2 articles in Science in 1992. The studies showed that $\mathrm{CD}^{+} \mathrm{T}$ cells participate in vivo in the resistance to disease induced during the natural history of experimental autoimmune encephalomyelitis (EAE), a well-studied model of the human disease multiple sclerosis $(59,60)$. For example, EAE is induced by myelin proteins such myelin basic protein (MBP), which activates encephalitogenic CD4+ Th1 cells. Mice of the B10PL strain completely recover from the first episode of EAE and become highly resistant to the reinitiation of EAE by secondary immunization. If these protected mice are then depleted of $\mathrm{CD}^{+} \mathrm{T}$ cells through the use of monoclonal anti-CD8, the protection is reversed, and the mice develop clinical EAE upon reimmunization with $\mathrm{MBP}$ (59). Furthermore, mice depleted of $\mathrm{CD}^{+} \mathrm{T}$ cells during the initial induction of EAE and allowed to recover normal levels of $\mathrm{CD}^{+} \mathrm{T}$ cells are not resistant and develop EAE again upon rechallenge with $\mathrm{MBP}$. Thus, $\mathrm{CD}^{+} \mathrm{T}$ cells require priming during the first episode of EAE to regulate $\mathrm{CD} 4^{+} \mathrm{T}$ cells triggered by secondary MBP stimulation in vivo. Moreover, when $\mathrm{CD}^{-/-}$mice are bred with EAE-susceptible $\mathrm{PL} / \mathrm{J}$ mice, the progeny of the $\mathrm{CD}^{-/-}$and $\mathrm{PL} / \mathrm{J}$ mating develop more chronic EAE than the wild-type PL/J mice, as reflected by a higher frequency of relapses (60). These experiments provide evidence that $\mathrm{CD}^{+} \mathrm{T}$ cells play a key role in both inducing resistance to autoimmune EAE and in abrogating or suppressing recurrent relapsing episodes of pathogenic autoimmunity in vivo.

These experiments set the stage for a series of studies designed to further delineate the cellular pathways involved in $\mathrm{CD}^{+} \mathrm{T}$ cell suppression. An unexpected consequence of these studies was the initial reemergence of the Qa-1 component of the suppressor story alluded to above. The key experiments involved the isolation of $\mathrm{CD}^{+} \mathrm{T}$ cells from EAE-recovered mice and showed that they functioned as suppressor cells and specifically downregulated or killed some but not all $\mathrm{MBP}$-activated $\mathrm{CD}^{+} \mathrm{T}$ cell clones. Importantly, the $\mathrm{CD}^{+}$suppressor cells were shown to preferentially suppress the potentially pathogenic autoreactive clones, and deletion of the $\mathrm{CD}^{+}$suppressor $\mathrm{T}$ cell was associated with recurrence of disease. Conversely, adoptive transfer or induction of the suppressor cells prevents disease. Thus, during the natural history of EAE, the $\mathrm{CD}^{+}$ suppressor T cells fine tune the MBP-reactive TCR repertoire even within the TCR V $\beta$ families that are preferentially activated by MBP in vivo (9). Analogous experiments using the superantigen staphylococcal enterotoxin B (SEB) showed that $\mathrm{CD}^{+} \mathrm{T}$ cells were involved in the downregulation of the $\mathrm{CD} 4^{+} \mathrm{T}$ cell response to SEB in vivo and in vitro (54). The specific inhibition of $\mathrm{CD}^{+}$ TCR V $\beta 8$ target $T$ cells in both the EAE and SEB experiments was blocked by monoclonal antibodies to the TCR $\alpha \beta$ and CD 8 but was not blocked by antibodies to MHC class 1a molecules. This was 


\section{A}

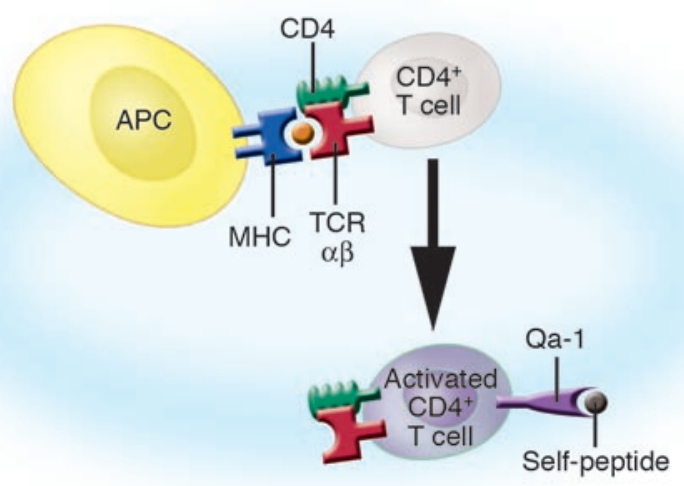

B

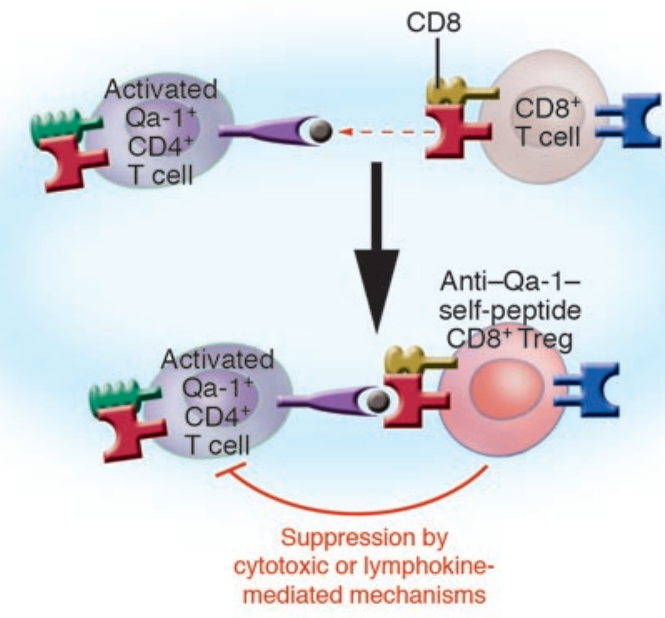

intriguing and suggested that perhaps the nonclassical MHC class $1 \mathrm{~b}$ molecules may play a role in vivo in restricting the suppression mediated by $\mathrm{CD}^{+} \mathrm{T}$ cells. Indeed, subsequent experiments in vivo showed that the suppression mediated by $\mathrm{CD}^{+}$suppressor $\mathrm{T}$ cells is blocked by antibodies to the MHC class $1 \mathrm{~b}$ Qa-1 molecule $(9,54$, 61). Importantly, the $\mathrm{Qa}-1^{+} \mathrm{CD} 4^{+} \mathrm{T}$ cells could be employed as vaccine $T$ cells and used to induce regulatory $\mathrm{CD}^{+} \mathrm{T}$ cells in vivo. This $\mathrm{T}$ cell vaccination procedure protected animals from developing EAE, and this protection was abrogated by depletion of the Qa-1restricted $\mathrm{CD}^{+} \mathrm{T}$ cells in vivo $(61,62)$.

In very recent experiments, the Cantor laboratory has created Qa-1-deficient mice and used them to directly demonstrate, in vivo, the important role that Qa-1 plays in the regulatory pathway mediated by $\mathrm{CD} 8+\mathrm{T}$ cells in the control of autoimmunity (56). The authors convincingly demonstrated that the Qa-1-deficient mice develop severe EAE when exposed to the myelin-associated self-proteolipid protein (self-PLP) peptide and fail to develop the resistance to EAE that normally develops in wild-type mice after immunization with PLP peptide. Furthermore, the failure of resistance to EAE is associated with the escape of Qa-1-deficient CD4 cells from $\mathrm{CD}^{+} \mathrm{T}$ cell suppression, which could be restored by lentiviral-based expression of the syngeneic Qa-1 allele. These results form the heart of the functional data on Qa-1-deficient mice, demonstrating the in vivo relevance of $\mathrm{Q} a-1$ in the control of autoimmunity. Furthermore, the authors also showed that Qa-1- deficient mice fail to control expansion of herpes simplex virus 1-induced (HSV-1-induced)

\section{Figure 2}

Model of cognate interactions in the induction and function of Qa-1restricted regulatory $\mathrm{CD} 8{ }^{+} \mathrm{T}$ cells. $(\mathrm{A})$ Initial activation of $\mathrm{CD} 4{ }^{+} \mathrm{T}$ cell TCRs with peptide-MHC complexes induces the expression of Qa-1 bound with a variety of self-peptides on the surface of the CD4+ $\mathrm{T}$ cells. (B) Anti-Qa-1-self-peptide CD8 ${ }^{+}$precursor T cells are activated by Qa-1-expressing CD4+ T cells. The Qa-1-restricted CD8+ Tregs selectively downregulate certain but not all antigen-activated $\mathrm{CD} 4^{+} \mathrm{T}$ cells based on the specific recognition of $\mathrm{Qa}$-1-self-peptide complexes expressed on certain CD4 ${ }^{+} \mathrm{T}$ cells by TCR $\alpha \beta$ on the CD8 ${ }^{+} \mathrm{T}$ cells. In this regard, we have demonstrated in the EAE model that self-reactive CD4 ${ }^{+} \mathrm{T}$ cells, which are selectively downregulated by the CD8 ${ }^{+} \mathrm{T}$ cells, are enriched in potentially pathogenic self-reactive T cell clones (9).

$\mathrm{CD} 4{ }^{+} \mathrm{Th} 1$ cells that induce ocular keratitis and blindness. These Th1 CD4 ${ }^{+} \mathrm{T}$ cells are specific for HSV peptides cross-reactive with self-corneal tissues and thus confirm the findings in another relevant autoimmune disease model. Moreover, these studies also show that the effect of Qa-1 on regulatory $\mathrm{CD}^{+} \mathrm{T}$ cells in the control of autoimmune disease in vivo is only observed during the secondary, but not the primary, immune response.

A number of biologic features of the Qa-1 molecule make it particularly interesting with respect to its role as a restricting element in immunoregulation. First, Qa-1 is preferentially expressed on activated, but not resting, $\mathrm{T}$ cells. Moreover, the fact that surface expression of Qa-1 on activated $\mathrm{T}$ cells is short lived may exclude resting $\mathrm{T}$ cells from downregulation by $\mathrm{Q} a-1-$ dependent $\mathrm{CD} 8^{+} \mathrm{T}$ cells. Second, Qa-1 is of limited polymorphism, with the potential to present self- and foreign peptides to $\mathrm{CD}^{+} \mathrm{T}$ cells. The predominant self-peptide presented by Qa- 1 is Qdm, a hydrophobic peptide (AMAPRTLLL) derived from the leader sequence of certain MHC class Ia molecules (63). However, during T cell activation, Qa-1 can also bind other hydrophobic self-peptides that may serve as target antigens for the $\mathrm{CD} 8^{+} \mathrm{T}$ cells, as described above. Because the Qa-1self-peptide complexes can interact with the CD94-NKG2 receptors expressed on NK or classical $\mathrm{CD}^{+} \mathrm{T}$ cells to either positively or negatively regulate function, Qa-1 may not only serve as the target of $\mathrm{CD} 8$ suppression, but also regulate the function of $\mathrm{CD} 8^{+}$suppressor $\mathrm{T}$ cells via the CD94-NKG2 receptors.

In summary, we envision that the CD8 $\mathrm{T}$ cell regulatory pathway comprises a series of sequential cellular events (Figure 2). It is initiated by the activation of naive $\mathrm{CD} 4^{+} \mathrm{T}$ cells during the primary immune response, in which the TCRs on $\mathrm{CD} 4^{+} \mathrm{T}$ cells interact with MHC class II-peptide complexes presented by conventional APCs. This initial interaction induces the surface expression of activation-dependent Qa-1-self-peptide complexes which is not observed in resting $\mathrm{T}$ cells. These activation-dependent $\mathrm{Qa}$-1-self-peptide complex serve as both the inducer and target structures recognized by TCR $\alpha \beta$ on regulatory $C D 8^{+} \mathrm{T}$ cells. Thus, the Qa-1-self-peptide complex expressed by activated CD $4^{+} \mathrm{T}$ cells triggers TCR $\alpha \beta$ on regulatory $\mathrm{CD}^{+} \mathrm{T}$ cells. These $\mathrm{CD} 8^{+} \mathrm{T}$ cells then differentiate into effector cells, which in turn suppress $\mathrm{CD} 4^{+} \mathrm{T}$ cells expressing the same target Qa-1-self-peptide complex. This suppression is linked to specific antigen activation of $\mathrm{CD} 4^{+} \mathrm{T}$ cells, and as a consequence the peptides bound by Qa-1 will likely be those induced by antigen activation. Whether they represent specific peptides derived from the CD4 T cell TCR (TCR V $\beta$ or V $\alpha$ peptides) or peptides derived from activation molecules induced by antigen triggering is not known. The mechanism of effecting suppression of the $\mathrm{CD} 4^{+} \mathrm{T}$ cells by the $\mathrm{Qa}-1$-restricted $\mathrm{CD}^{+} \mathrm{T}$ cells has not been definitively 
delineated; however, the consequences of TCR triggering of CD8 ${ }^{+}$ $\mathrm{T}$ cell precursors may be conventional and involve differentiation into specific CTLs that lyse target cells and/or secrete lymphokines that downregulate the target cells.

Furthermore, it has also been shown that a distinct population of antigen-specific, non-Qa-1-restricted CD8 ${ }^{+} \mathrm{CD} 28^{-}$cells can suppress immune responses by directly interacting with antigenpresenting DCs and rendering these cells tolerogenic (64-66). The suppression involves the upregulation of inhibitory Ig-like transcript 3 (ILT3) and ILT4 receptors expressed on the DCs. APCs tolerized by $\mathrm{CD}^{+} \mathrm{T}$ cells show reduced expression of costimulatory molecules and induce antigen-specific unresponsiveness in $\mathrm{CD}^{+}$ $\mathrm{T}$ helper cells. The precise function of these cells in vivo is not clear, and it is not known whether they interact with the Qa-1-restricted $\mathrm{CD}^{+}$suppressor cells or, alternatively, whether Qa-1-restricted T cells induce tolerogenic DCs.

Finally, the Qa-1-dependent regulatory CD8 pathway has begun to be translated from mice to humans with the in vitro findings that human $\mathrm{CD}^{+} \mathrm{T}$ cells can be induced to differentiate into regulatory cells whose function is dependent on HLA-E, the human homolog of Qa-1 $(67,68)$. These data support the idea that clinically relevant methods to induce and/or enhance this suppressive pathway in humans may prove useful in the prevention and treatment of human autoimmune disease. The details of several of the points in this section will be expanded upon in the series reviews from the Cantor and Kumar laboratories $(13,14)$.

The rapid rise of $\mathrm{CD}^{+}$suppressor $T$ cells. Although suppressor cells were initially identified within the $\mathrm{CD}^{+} \mathrm{T}$ cell population (49, $50,69)$, it was later found that suppressor cell function could be mediated by $\mathrm{CD}^{+} \mathrm{T}$ cells independent of $\mathrm{CD}^{+} \mathrm{T}$ cells $(50,70-72)$. For example, in the early 1980s, it was shown that coculture of graded numbers of polyclonally activated human $\mathrm{CD}^{+} \mathrm{T}$ cells to autologous resting $\mathrm{CD}^{+} \mathrm{T}$ cells inhibited the capacity of the resting $\mathrm{CD}^{+} \mathrm{T}$ cells to induce $\mathrm{B}$ cell differentiation and Ig synthesis in vitro $(73,74)$. The in vivo significance of these findings in humans were unknown. However, in vivo experiments in mice in the mid-1980s placed the idea of $\mathrm{CD}^{+}$suppressor cells on a firmer biological foundation. In particular, studies by Sakaguchi and colleagues on the organ-specific autoimmune disease induced in mice following neonatal thymectomy were quite revealing. These thymectomized mice were shown to have reduced numbers of $\mathrm{CD}^{+}$as well as $\mathrm{CD}^{+} \mathrm{T}$ cells. Furthermore, reconstitution of thymectomized mice by highly enriched populations of $\mathrm{CD} 4^{+}$but not $\mathrm{CD}^{+} \mathrm{T}$ cells from syngeneic normal mice completely inhibited disease development (70).

A decade later in 1995, Sakaguchi showed for the first time that the suppression mediated by $\mathrm{CD}^{+} \mathrm{T}$ cells is a function of the small subset of $\mathrm{CD} 4^{+} \mathrm{CD} 25^{+}$cells $(71)$. The transfer of T cells depleted in the $\mathrm{CD} 4{ }^{+} \mathrm{CD} 25^{+}$population into nude (athymic) mice led to a variety of autoimmune diseases, which could be prevented by injection of purified $\mathrm{CD} 4^{+} \mathrm{CD} 25^{+} \mathrm{T}$ cells but not $\mathrm{CD} 4^{+} \mathrm{CD} 25^{-} \mathrm{T}$ cells. The field of $\mathrm{CD} 4^{+} \mathrm{CD} 25^{+}$regulator cells, termed "CD4 ${ }^{+} \mathrm{CD} 25^{+}$Tregs," was thus born and has experienced an explosive growth over the past few years $(75,76)$. Thus, the general experimental protocols employed to characterize these suppressor cells in vivo took advantage of the observation that mice deficient in T cells (neonatally thymectomized, $n u / n u$ mice or $\mathrm{Rag}^{-1-}$ mice) do not develop autoimmune disease following adoptive transfer of normal syngeneic spleen cells unless the spleen cells are depleted of $\mathrm{CD} 4{ }^{+} \mathrm{CD} 25^{+} \mathrm{T}$ cells. Thus, when
$\mathrm{CD}^{+}$splenic $\mathrm{T}$ cells prepared from normal mice were depleted of $\mathrm{CD}_{25} 5^{+}$cells and the remaining $\mathrm{CD}^{+} \mathrm{T}$ cells were transferred to syngeneic $\mathrm{T}$ cell-deficient mice, the recipients spontaneously developed various organ-specific autoimmune diseases (including type 1 diabetes [T1D], thyroiditis, and gastritis) and systemic wasting disease. Reconstitution of the $\mathrm{CD} 4{ }^{+} \mathrm{CD} 25^{+}$population inhibited the autoimmune development $(72,76)$. However, it is becoming increasingly clear that in many situations, $\mathrm{CD} 4^{+} \mathrm{CD} 25^{-}$ $\mathrm{T}$ cells are as effective as $\mathrm{CD} 4^{+} \mathrm{CD} 25^{+} \mathrm{T}$ cells in controlling $\mathrm{T}$ cellmediated disease $(77,78)$.

In this regard, seminal studies of the potency of suppressor T cells by Lafaille and colleagues unequivocally showed that very small numbers of $\mathrm{CD}^{+}$suppressor cells can regulate immune responses in vivo independent of $\mathrm{CD}^{+} \mathrm{T}$ cells. This set of studies evaluated TCR-transgenic mice expressing the MBP specific for the TCR expressed on pathogenic clones and known to induce EAE $\left(T / R^{+}\right.$ mice). Lafaille found that these $\mathrm{T} / \mathrm{R}^{+}$mice rarely develop spontaneous EAE. However, when the $\mathrm{T} / \mathrm{R}^{+}$mice are crossed with $R a g 1^{-/-}$ mice to obtain mice that have only $\mathrm{T}$ cells expressing the transgenic MBP-specific TCR ( $\mathrm{T} / \mathrm{R}^{-}$mice), almost all mice develop spontaneous EAE (79). Because both $T / R^{+}$and $T / R^{-}$mice have large numbers of the potentially encephalitogenic $\mathrm{CD}^{+}$anti-MBP $\mathrm{T}$ cells, these results suggest that a very small number of nontransgenic lymphocytes, which are present in $\mathrm{T} / \mathrm{R}^{+}$but absent in $\mathrm{T} / \mathrm{R}^{-}$mice, can potently suppress the in situ activation of $\mathrm{CD}^{+}$anti-MBP $\mathrm{T}$ cells mediating EAE. To identify the cellular regulatory mechanisms important in this suppression, $\mathrm{T} / \mathrm{R}^{+}$mice were crossed into mice deficient in either B cells, CD8 ${ }^{+} \mathrm{T}$ cells, NKT cells, TCR $\gamma \delta$ cells, or TCR $\alpha \beta$ cells $(80,81)$. Only mice that were deficient in $\mathrm{CD}^{+} \alpha \beta \mathrm{T}$ cells developed EAE. Moreover, $\mathrm{T} / \mathrm{R}^{-}$mice were protected from $\mathrm{EAE}$ by the early (that is, prior to the onset of EAE) adoptive transfer of purified $\mathrm{CD}^{+} \mathrm{T}$ cells from normal donors. These results support the view that under certain experimental conditions $\mathrm{CD} 4^{+}$cells alone can suppress the initiation of autoimmunity. Moreover, it was subsequently shown that both $\mathrm{CD} 4^{+} \mathrm{CD} 25^{+}$and $\mathrm{CD} 4^{+} \mathrm{CD} 25^{-}$ cells could mediate this suppression $(78,82)$.

The precise relationship between the $\mathrm{CD} 4^{+} \mathrm{CD} 25^{+}$and $\mathrm{CD} 4^{+} \mathrm{CD} 25^{-}$regulatory cells is not clear. As described above, the intrinsic homeostatic regulatory mechanisms pertaining to all $\mathrm{CD}^{+} \mathrm{T}$ cells - including AICD, costimulatory molecules (CD40L/ CD40, CD28, or CTLA-4/B7), cytokine secretion and differentiation into Th1, Th2, and $\operatorname{Tr} 1$ subsets - are involved to some degree in the regulation of all immune responses independent of suppressor cells, so that the relationship between these known intrinsic mechanisms and suppressor cell function is of paramount importance. This is a particularly important issue with respect to regulation by $\mathrm{CD} 4^{+} \mathrm{CD} 25^{+}$suppressor $\mathrm{T}$ cells, because at the present time, there are no known cell surface molecules that uniquely distinguish the $\mathrm{CD}^{+}$suppressor cells from conventional activated $\mathrm{CD}^{+}$ cells. For example, the CD25 molecule, which is the $\alpha$-chain of the IL-2 receptor, is expressed on all peripheral antigen-reactive $\mathrm{CD}^{+}$ $\mathrm{T}$ cells from one to several days following antigen activation. Moreover, many of the other cell-surface molecules in addition to CD25 that seem to distinguish $\mathrm{CD} 4^{+} \mathrm{CD} 25^{+}$from $\mathrm{CD} 4^{+} \mathrm{CD} 25^{-}$Tregs are upregulated on $\mathrm{CD} 4^{+} \mathrm{CD} 25^{-} \mathrm{T}$ cells following antigen activation. These molecules are therefore not unique differentiation antigens that define functional subsets but in fact are $\mathrm{T}$ cell activation molecules that are like CTLA-4, the glucocorticoid-induced TNF receptor family-related gene (GITR), and CD45RO (76, 78, $83,84)$, which are expressed on the majority of $\mathrm{CD}^{+} \mathrm{T}$ cells follow- 


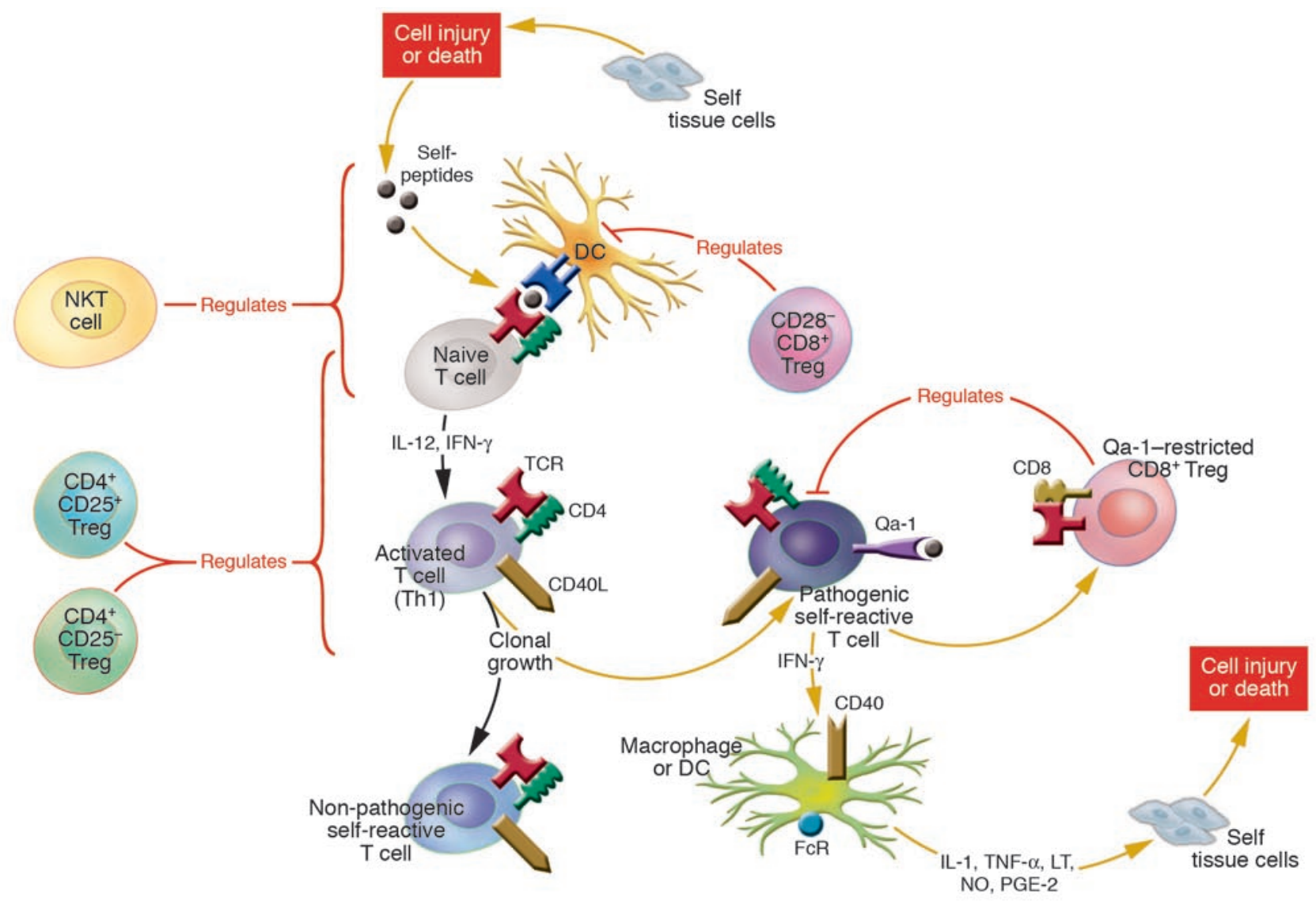

Figure 3

Tregs control the peripheral induction and clonal outgrowth of antigen-reactive $T$ cells. This illustration shows various pathways of immunoregulation mediated by suppressor subsets of $\mathrm{NKT}, \mathrm{CD} 4^{+}$, and $\mathrm{CD} 8^{+} \mathrm{T}$ cell subsets. Each of the regulatory $\mathrm{T}$ cell subsets expresses distinct receptors, employs different effector mechanisms, and functions predominately at different stages during the course of the peripheral immune response. The NKT and CD4+CD25+ regulatory cells are "natural suppressor cells"; they are present prior to antigen activation and primarily function during the early "innate" and/or primary adaptive immune responses. In contrast, the CD8+ regulatory cells are induced to differentiate into suppressor effector cells during the primary immune response, and they function as effector-suppressor cells predominately during the secondary and memory phases of immunity.

ing antigen triggering of the TCR. The CTLA- 4 may be of special interest with respect to the function of $\mathrm{CD} 4{ }^{+} \mathrm{CD} 25^{+}$regulatory cells because, like CD25, CTLA-4 is thought to be constitutively expressed on the $\mathrm{CD} 4^{+} \mathrm{CD} 25^{+}$suppressor populations (85), and blockade of the CTLA-4 interactions with their CD80 or CD86 receptors in vivo can abrogate suppression. Moreover, $\mathrm{T}$ cells triggered via CTLA- 4 predominantly secrete TGF- $\beta$, a cytokine with suppressive functions (86). On the other hand, in vitro experiments have not been able to document a blocking effect of anti-CTLA-4 on suppressor cell function (87). The search is still on to define specific markers that distinguish the subsets of $\mathrm{CD}^{+}{ }^{+}$suppressor subsets $(78,83,84)$. This general issue will be further discussed in several review articles in this series (particularly refs. 10-12).

With respect to the general role of cytokines in the suppression mediated by $\mathrm{CD}^{+}$Tregs, the cytokine profiles found in the various populations of $\mathrm{CD}^{+}$suppressor cells include a variety of combinations of the already-known immunoregulatory cytokines (i.e., IL-10, TGF- $\beta$, IL-4, IFN- $\gamma$ ). For example, there are $\mathrm{CD} 4^{+} \mathrm{CD} 45 \mathrm{Rb}^{\text {low }}$ activated suppressor cells that secrete large quantities of either IL-10 and IL-4 (termed Tr1 cells) and other $\mathrm{CD}^{+} \mathrm{CD} 45 \mathrm{Rb}^{\text {low }}$ suppressor $\mathrm{T}$ cells that secrete large quantities of
TGF- $\beta$ (termed Th3 cells) (38). (The role of IL-10 cytokine expression will be discussed in detail in the series review by O'Garra et al., ref. 11) The functional significance of these cytokine-secreting $\mathrm{CD}^{+} \mathrm{T}$ cells is supported by the findings that TGF- $\beta$-deficient mice develop autoimmune disease (88) and that administration of neutralizing antibodies to IL- 4 or TGF- $\beta$ abrogates the in vivo prevention of autoimmunity or tolerance-inducing activity of $\mathrm{CD}^{+} \mathrm{T}$ cells in some models $(89,90)$. The relationship of these cells to the $\mathrm{CD} 4^{+} \mathrm{CD} 25^{+} \mathrm{CTLA}-4^{+}$cells is unclear. For example, the in vitro capacity of $\mathrm{CD} 4^{+} \mathrm{CD} 25^{+} \mathrm{T}$ cells to suppress immune responses is known to be contact dependent and not due to the IL-10, TGF- $\beta$, and IL-4 cytokines alone. It is possible the $\operatorname{Th} 3$ and $\operatorname{Tr} 1$ populations arise from "conventional" resting $\mathrm{CD} 4^{+} \mathrm{CD} 25^{-} \mathrm{T}$ cells, which, following antigen activation, express $\mathrm{CD} 25$. Taken together, these data may suggest that $\mathrm{CD} 4^{+} \mathrm{CD} 25^{-}$ $\mathrm{T}$ cells, which function to suppress immune responses in vivo, may not represent a lineage-specific suppressor population. In contrast, the naturally occurring $\mathrm{CD} 4^{+} \mathrm{CD} 25^{+} \mathrm{T}$ cells responsible for preventing autoimmunity in neonatal immune-deficient mice are thought to represent a lineage-specific suppressor population arising directly from the thymus (76). 
In this regard, it is of great interest that a recently cloned transcription factor, termed Foxp3, a member of the forkhead family of DNA binding transcription factors, is not expressed in naive $\mathrm{CD} 4^{+} \mathrm{CD} 25^{-}$cells but is highly expressed in the naturally occurring $\mathrm{CD}^{+} \mathrm{CD} 25^{+}$regulatory cells. Importantly, mutational defects in the Foxp3 gene result in the fatal autoimmune and inflammatory disorder of the scurfy mouse and in the clinical and molecular features of the immunodysregulation, polyendocrinopathy, enteropathy, X-linked syndrome (IPEX syndrome) in humans. Both scurfy mice and IPEX patients have defects in T cell activation and reduced numbers and reduced suppressor functions mediated by the $\mathrm{CD} 4^{+} \mathrm{CD} 25^{+} \mathrm{T}$ cells (91-93). In Foxp3-overexpressing mice, both $\mathrm{CD}^{+}{ }^{+} \mathrm{CD} 25^{-}$and $\mathrm{CD} 4-\mathrm{CD} 8^{+} \mathrm{T}$ cells show suppressive activity, which suggests that expression of Foxp 3 is linked to suppressor functions (94). Taken together, these data strongly support the idea that Foxp3 may uniquely define the subset of naturally occurring $\mathrm{CD}^{+}$suppressor $\mathrm{T}$ cells. However, the recent findings that Foxp 3 can be expressed in $\mathrm{CD}^{+}{ }^{+} \mathrm{CD} 25^{-}$cells following activation and are also expressed in activated $\mathrm{CD}^{+} \mathrm{T}$ cells suggest that Foxp 3 is linked to functional suppression but not necessarily as a specific lineage marker (95-98).

Finally, the identity of the receptors that enable the $\mathrm{CD} 4^{+} \mathrm{CD} 25^{+}$ suppressor $T$ cells to preferentially suppress self-reactive $T$ cells and yet preserve normal immune functions remains a major unresolved issue. This apparent cognitive capacity to distinguish self from nonself is on the surface difficult to reconcile with a number of studies that have provided convincing evidence that the suppression mediated by $\mathrm{CD} 4^{+} \mathrm{CD} 25^{+}$Tregs is not antigen specific (87). Thus, in elegant experiments, the Shevach laboratory showed that when $\mathrm{T}$ cells from TCR transgenic mice are activated with their peptide-MHC ligand and expanded in vitro in IL-2, the activated suppressors are subsequently capable of suppressing the responses of T cells from mice that express a different transgenic TCR $(87,99)$. Moreover, no $\mathrm{MHC}$ restriction is observed in the interaction of the activated suppressors and the responding targets (100). Thus, the TCRs employed by these regulatory $\mathrm{CD}^{+} \mathrm{T}$ cells are likely to be quite diverse, and it is unknown whether their capacity to distinguish self from non-self is dependent of the TCR $\alpha \beta$ they express. Insight into the mechanism by which these antigen-nonspecific $T$ cells can still distinguish self from non-self may come from recent studies showing that the $\mathrm{CD} 4^{+} \mathrm{T}$ regulatory cells when nonspecifically activated by LPS express toll-like receptors (101). Thus, these naturally occurring Tregs may represent the regulatory component of the innate immune system responsive to "danger-like signals." Perhaps self-reactive T cells preferentially express ligands that are recognized by toll-like receptors expressed by the regulatory cells. Clearly, the elucidation of the precise target structures recognized by $\mathrm{CD} 4^{+} \mathrm{CD} 25^{+}$Tregs may help define the receptors employed by the regulatory cells to distinguish self from non-self. In contrast, as noted above, the $\mathrm{Qa}$-1-restricted $\mathrm{CD}^{+}$suppressor $\mathrm{T}$ cells are not naturally occurring cells but instead are specifically induced during the primary adaptive immune response and are triggered to differentiate into effector-suppressor cells, which distinguish among the clones of autoreactive cells responding to a single peptide. Unlike the naturally occurring $\mathrm{CD} 4{ }^{+} \mathrm{CD} 25^{+}$suppressor T cells, Qa-1restricted, $\mathrm{CD}^{+}{ }^{+}$suppressor T cells employ their TCR $\alpha \beta$ to recognize and distinguish targets of suppression.

NKT cells. NKT cells are a unique population of cells that express receptors of the NK lineage as well as a TCR $\alpha \beta$. Murine NKT cells express an invariant TCR $\alpha$ chain encoded by the V $\alpha 14$ -
J $\alpha 281$ gene segment, paired preferentially to various $V \beta$ chains (102). Human NKT cells express the Va24-JaQ invariant chain. The NKT cells recognize and kill tumor cells expressing lipid antigens structurally related to the glycolipid $\alpha$-galactosylceramide $(\alpha$-GalCer). These lipids are presented to NKT cells by the MHC class Ib molecule CD1d (103). Analogous CD1d-restricted NKT cells, which express the invariant V $\alpha 24-J \alpha Q$ TCR, are also present in humans $(104,105)$. The CD1d-restricted NKT cells are mainly of $\mathrm{CD}^{+}$or $\mathrm{CD}^{-}{ }^{-} \mathrm{CD} 8^{-}$phenotype (106), and although originally functionally defined, both in vivo and vitro, by their capacity to lyse a variety of tumor cells (107), they were later found also to be involved in the regulation of autoimmune diseases $(108,109)$. These in vivo roles in immune responses are thought to be linked to the fact that following TCR antigen triggering in vivo, NKT cells were observed to develop augmented killer cell activity and secrete large amounts of cytokines, including IL-4 and IFN- $\gamma$, as well as TGF- $\beta$ and IL-10 (103, 110-112), known to be involved in the activation of cell types important in mediating both innate immunity and Th2-type adaptive immunity.

As a consequence, NKT cells have been shown to influence the course of autoimmune disease in a variety of animal models. Prominent among the diseases affected by NKT cells are those primarily induced by Th1 cells, including the NOD diabetes model and the EAE models of multiple sclerosis $(109,113,114)$. In these diseases, the evidence strongly suggests that the Th2-favoring cytokines, IL-4 and IL-10, secreted by NKT cells play an important role (111, $115,116)$. Adoptive transfer of cell populations enriched for NKT cells prevents T1D in NOD recipients $(115,117,118)$. Moreover, depletion of NKT cells early in the evolution of diabetes in the NOD mice accelerates the onset of diabetes (119). For example, it was found that lack of CD1-restricted NKT cells promotes the development of diabetes, whereas activation of V $\alpha 14^{+} \mathrm{NKT}$ cells by $\alpha$-GalCer suppresses disease in the NOD model. Similarly, models of colitis or multiple sclerosis (EAE) depletion of NKT cells accelerates the onset of disease, whereas in vivo activation of NKT cells by treatment with the glycolipid ligand induces significant improvement or prevents disease. These effects are abrogated in CD1d-deficient mice.

A reduction in number or altered function of NKT cells has also been correlated with autoimmune disease in humans. In patients with multiple sclerosis who are in relapse or remission, the frequency of V $\alpha 24-J \alpha Q$ NKT cells is reduced in comparison with normal donors or patients with other autoimmune/inflammatory neurological diseases. In addition, diabetic individuals had lower frequencies of $V \alpha 24-J \alpha Q$ NKT cells in comparison with their nondiabetic monozygotic twins (120). The few V $\alpha 24-J \alpha Q$ NKT cell clones that could be isolated from these diabetic patients were deficient in IL-4 production. Taken together, these studies suggested the hypothesis that NKT cells play a role in natural protection against destructive Th1-mediated autoimmunity in T1D. However, a more recent study comparing diabetic patients and healthy controls, including discordant twin pairs, demonstrates that NKT cell frequency and IL-4 production are conserved during the course of T1D. These results do not necessarily refute the hypothesis that NKT cell defects underlie T1D but may indicate that immunoregulation of autoimmune disease is mediated by several subsets of immunoregulatory cells functioning in concert (121). Thus, in any particular patient, autoimmunity may not reflect not a single deficiency in one subset, but instead a defect in an integrated system of immunoregulation mediated at different levels by distinct $T$ cell subsets. 
Table 1

Properties of Treg subsets

\begin{tabular}{|c|c|c|c|c|c|c|}
\hline \multirow[t]{2}{*}{$\begin{array}{l}\text { Subsets } \\
\text { of Tregs }\end{array}$} & \multirow[t]{2}{*}{$\begin{array}{l}\text { Target cells } \\
\text { of suppression }\end{array}$} & \multicolumn{2}{|c|}{$\begin{array}{l}\text { Molecular interaction between regulatory } \\
\text { cells and inducer/target cells }\end{array}$} & \multirow{2}{*}{$\begin{array}{l}\text { Stage of } \\
\text { immunity } \\
\text { affected }\end{array}$} & \multirow[t]{2}{*}{$\begin{array}{l}\text { Regulatory } \\
\text { mechanisms }\end{array}$} & \multirow[t]{2}{*}{$\begin{array}{l}\text { In vivo } \\
\text { function }\end{array}$} \\
\hline & & Induction phase & Effector phase & & & \\
\hline NKT cells & $\begin{array}{l}\text { Tumor cells, } \\
\text { pathogen- } \\
\text { activated T cells, } \\
\text { and/or APCs }\end{array}$ & $\begin{array}{l}\text { TCR recognizing } \\
\text { CD1d/glycolipid; } \\
\text { restricted by CD1d }\end{array}$ & $\begin{array}{l}\text { Same as } \\
\text { induction phase }\end{array}$ & Natural; innate & $\begin{array}{l}\text { IL- } 4, \text { IL-10, } \\
\text { TGF- } \beta \text {, IFN- } \gamma \text {; } \\
\text { cytotoxicity }\end{array}$ & $\begin{array}{l}\text { Destruction of } \\
\text { tumors and pathogens; } \\
\text { regulation of Th1- } \\
\text { mediated autoimmune } \\
\text { diseases }\end{array}$ \\
\hline $\begin{array}{l}\text { CD4+CD25- } \\
\text { Tregs }\end{array}$ & $\begin{array}{l}\text { T and B cells; } \\
\text { ?APCs }\end{array}$ & $\begin{array}{l}\text { Activated by MHC } \\
\text { class II-peptide } \\
\text { nonspecifically }\end{array}$ & $\begin{array}{l}\text { May function by } \\
\text { elaborating cytokines }\end{array}$ & Primary early & $\begin{array}{l}\text { Predominately } \\
\text { mediated } \\
\text { by cytokines }\end{array}$ & $\begin{array}{l}\text { Suppression of a } \\
\text { variety of } \\
\text { autoimmune diseases }\end{array}$ \\
\hline $\begin{array}{l}\text { CD4+CD25+ } \\
\text { Tregs }\end{array}$ & $\begin{array}{l}\text { T cells; } \\
\text { ?APCs }\end{array}$ & $\begin{array}{l}\text { Activated by } \\
\text { MHC class II-peptides } \\
\text { nonspecifically }\end{array}$ & $\begin{array}{l}\text { Target and specificity } \\
\text { is unknown; } \\
\text { suppression is not } \\
\text { MHC restricted }\end{array}$ & Primary earlyA & $\begin{array}{l}\text { Requires cell-cell } \\
\text { contact, cytokines }\end{array}$ & $\begin{array}{l}\text { Prevention of a variety } \\
\text { of autoimmune } \\
\text { diseases, regulation of } \\
\text { allograft rejection; } \\
\text { immune response } \\
\text { to pathogens }\end{array}$ \\
\hline $\begin{array}{l}\text { Qa-1- } \\
\text { restricted } \\
\text { CD8+ Tregs }\end{array}$ & $\begin{array}{l}\text { Antigen-activated } \\
\text { T cells differentially } \\
\text { expressing Qa-1- } \\
\text { self-peptide } \\
\text { complexes }\end{array}$ & $\begin{array}{l}\text { TCR recognizing } \\
\text { Qa-1/hydrophobic } \\
\text { self-peptides; } \\
\text { restricted by Qa-1 }\end{array}$ & $\begin{array}{l}\text { Same as induction } \\
\text { phase }\end{array}$ & Secondary late ${ }^{A}$ & $\begin{array}{l}\text { Cytotoxicity; } \\
\text { requires cell-cell } \\
\text { contact, ?cytokines }\end{array}$ & $\begin{array}{l}\text { Fine tuning peripheral } \\
\text { TCR repertoire; } \\
\text { maintaining self- } \\
\text { tolerance and } \\
\text { controlling } \\
\text { autoimmune disease }\end{array}$ \\
\hline $\begin{array}{l}\text { CD8+CD28- } \\
\text { Tregs }\end{array}$ & DCs & $\begin{array}{l}\text { Activated by } \\
\text { classical MHC } \\
\text { class la-peptide, } \\
\text { nonspecifically? }\end{array}$ & $\begin{array}{l}\text { Target of suppression } \\
\text { is unknown }\end{array}$ & Primary early & $\begin{array}{l}\text { Upregulation of } \\
\text { ILT3 and ILT4 } \\
\text { on DCs }\end{array}$ & $\begin{array}{l}\text { Possibly regulation of } \\
\text { autoimmunity }\end{array}$ \\
\hline
\end{tabular}

${ }^{A} \mathrm{CD} 4{ }^{+} \mathrm{CD} 25^{+}$Tregs isolated from naive unprimed mice protect recipient animals from autoimmune diseases when adoptively transferred. In contrast, Qa-1-restricted CD8 ${ }^{+}$Tregs require priming during primary immune response in order to regulate the secondary immune response in vivo.

Thus, as a member of the family of immunocompetent cells participating in the innate immune response, NKT cells are positioned to influence and interact with other Tregs during the early phases of the autoimmune response (122). Their interaction with $\mathrm{CD}^{+} \mathrm{T}$ cells is implicit in their capacity to secrete cytokines such as IL-4 and IL-10 that may shift the Th1-Th2 balance. In addition, there is evidence that NKT cells also interact with $\mathrm{CD}^{+} \mathrm{T}$ cells in immunoregulation (123). The mechanisms through which NKT cells may regulate tolerance induction are complex and involve interactions with $\mathrm{CD}^{+}$and $\mathrm{CD}^{+}$regulatory cells. The complexity of how NKT cells are involved in regulating immune responses is the topic of the series review by Godfrey and Kronenberg (15).

\section{An integrated overview of immunoregulation by NKT, CD4+CD25+, and Qa-1-restricted CD8+ T cell subsets}

The resurgence of interest in immunosuppression mediated by $\mathrm{T}$ cells during the last decade has come from several distinct lines of investigation that have led to the concept that the immune system has evolved a variety of regulatory mechanisms mediated by distinct $T$ cell subsets to suppress the outgrowth of potentially pathogenic self-reactive $T$ cells. The regulation mediated by these suppressor subsets is superimposed on intrinsic regulatory mechanisms induced by the initial encounter of the TCR with antigen (Figure 3). These mechanisms include the induction of: (a) cell death if the encounter is of very high affinity; (b) nonresponsiveness if the encounter occurs in the absence of appropriate costimulatory signals; and (c) the antigen-triggered differentiation into various Th subsets that secrete distinct arrays of Th1, Th2, $\operatorname{Tr} 1$, or $\operatorname{Tr} 3$ regulatory cytokines.

Given this intricate set of intrinsic regulatory mechanisms, one can legitimately ask why the immune system evolved an extrinsic set of regulatory mechanisms dependent on suppressor cells. The answer is simply that in the absence of $\mathrm{T}$ cell suppression, the intrinsic mechanisms are not sufficient to prevent autoimmunity or dampen immune responses to prevent collateral immune injury. To begin to understand the important interplay between the intrinsic and extrinsic mechanisms, it is important to emphasize that each of the extrinsic T cell suppressor subsets express distinct receptors, employ different effector mechanisms, and function at different stages during the evolution of immune responses (see Table 1). Thus, the NKT cells and $\mathrm{CD} 4{ }^{+} \mathrm{CD} 25^{+}$regulatory cells exist from the very early stages of life as "natural suppressor cells" prior to antigen activation and primarily function during the "innate" and/or primary immune responses. The NKT cells are endowed with pauciclonal TCR $\alpha \beta$ s consisting of an invariant $V \alpha$ chain that specifically permits recognition of glycolipid molecules often expressed by various pathogens and presumably also expressed by tumor cells, activated blasts, and injured apoptotic cells that arise at the inception of immune responses. These NKT cells are thus poised to secrete IL-4 and IL-10, which are known to influence the balance of Th1 or Th2 cells that emerge during the primary immune response. 
Cells of the naturally occurring $\mathrm{CD} 4^{+} \mathrm{CD} 25^{+}$suppressor subset, which are capable of suppressing the outgrowth of autoreactive cells, also exist in the peripheral lymphoid system. These cells, like the NKT cells, can function during the primary immune response and do not require specific induction. In vitro, the suppressor function of these cells can be shown to dependent of cell-cell contact, but they can also express immunoregulatory cytokines including TGF- $\beta$, which may be involved in the their suppressor function in vivo. The precise specificity of these cells for their targets remains unknown, and it is not clear whether APCs and/or T cells are the targets of $\mathrm{CD} 4^{+} \mathrm{CD} 25^{+}$-mediated suppression. Moreover, although the $\mathrm{CD}^{+} \mathrm{CD} 25^{+}$suppressor cells express conventional TCR $\alpha \beta$, the evidence suggests that these TCRs are not involved in the direct recognition of the targets of suppression.

In contrast to both the NKT cells and the naturally occurring $\mathrm{CD}^{+}{ }^{+} \mathrm{CD} 25^{+}$regulatory cells, the $\mathrm{Qa}-1$-restricted $\mathrm{CD} 8^{+}$Tregs are not prevalent in naive animals prior to antigen encounter. As a consequence, adoptive transfer of $\mathrm{CD}^{+} \mathrm{T}$ cells from naive animals has no effect on the outcome of autoimmune responses, and depletion of $\mathrm{CD}^{+} \mathrm{T}$ cells prior the first induction of autoimmunity has no effect on the first episode of disease either. However, the CD8 ${ }^{+}$ regulatory cells function like classical immunocompetent cells activated during adaptive immune responses. Thus, the they are induced by autologous $\mathrm{CD}^{+} \mathrm{T}$ cells activated during the primary immune response and differentiate into effector-suppressor cells, which function predominately during the secondary and memory phases of immunity. Thus, adoptive transfer of $\mathrm{CD}^{+} \mathrm{T}$ cells from self-antigen-primed mice will retard the outgrowth of the potentially pathogenic self-reactive $\mathrm{T}$ cells. In this regard, it is of interest that $\mathrm{CD}^{+}$Tregs are known to mediate resistance to autoimmunity following initial recovery from disease and to decrease the incidence and severity of relapse of the disease. In contrast to the $\mathrm{CD}^{+} \mathrm{CD} 25^{+} \mathrm{T}$ cells, the $\mathrm{CD} 8^{+}$Tregs utilize their TCR $\alpha \beta$ s to directly recognize target cells in an MHC-restricted fashion. Thus, the $\mathrm{CD}^{+}$Tregs are Qa-1 restricted and selectively downregulate certain but not all activated $T$ cells that preferentially express Qa-1self-peptide(s) on their surface. They are poised to fine tune the immune response to suppress new or renewed outgrowth of

1. Ehrlich, P. 1900. The Croonian lecture: on immunity with special reference to cell life. Proc. Royal Soc. London. 66:424.

2. Jerne, N.K. 1955. The natural selection theory of antibody formation. Proc. Natl. Acad. Sci. U. S. A. 41:849.

3. Jerne, N.K. 1976. The immune system: a web of V domains. In The Harvey Lectures 70. Academic Press. New York, New York, USA. 93-110.

4. Burnet, F.M. 1957. A modification of Jerne's theory of antibody production using the concept of clonal selection. Australian Journal of Science. 20:67-69.

5. Alt, F.W., Blackwell, T.K., DePinho, R.A., Reth, M.G., and Yancopoulos, G.D. 1986. Regulation of genome rearrangement events during lymphocyte differentiation. Immunol. Rev. 89:5-30.

6. Goldrath, A.W., and Bevan, M.J. 1999. Selecting and maintaining a diverse T-cell repertoire. Nature. 402:255-262

7. Bouneaud, C., Kourilsky, P., and Bousso, P. 2000 Impact of negative selection on the $T$ cell repertoire reactive to a self-peptide: a large fraction of $\mathrm{T}$ cell clones escapes clonal deletion. Immunity. 13:829-840.

8. Kuchroo, V.K., et al. 2002. T cell response in experimental autoimmune encephalomyelitis (EAE): role of self and cross-reactive antigens in shaping, tuning, and regulating the autopathogenic $\mathrm{T}$ cell repertoire. Annu. Rev. Immunol. 20:101-123. autoreactive cells during episodes of relapse from autoimmune disease. These suppressor cells thus represent more the adaptive suppressive response to immunity, whereas the $\mathrm{CD}^{+}{ }^{+}$and NKT suppressor subsets mediate natural immunity to the outgrowth of potentially pathogenic cells.

In summary, in this introductory JCI series article, we emphasized the idea that immunoregulation is carried out in an integrated manner by distinct suppressor $\mathrm{T}$ cells subsets that are superimposed on intrinsic homeostatic control mechanisms. Understanding the precise interplay between these intrinsic and suppressor mechanisms will undoubtedly be involved in the immunopathogenesis of a variety of diseases associated with abnormalities in immunoregulation. The evidence that distinct suppressor subsets are involved in many autoimmune states has been alluded to above and will be highlighted in greater detail in subsequent articles in this series $(10,13-15)$. In addition, the series will review the mounting evidence that suppressor cells are important in the immunopathogenesis of infectious and allergic diseases $(11,16)$ as well as allograft rejection (12). Finally, the idea that clinical induction of suppressor mechanisms may be important in the control of immunologic disease was conceived in the early days of the study of suppressor T cells. Induction of suppressor mechanisms by $\mathrm{T}$ cell vaccination to prevent autoimmunity, the study of which was pioneered by Irun Cohen in the early 1980s, was recently shown to involve suppressor $\mathrm{T}$ cells, as noted above. In this regard, the series will include a review of recent ideas concerning the immunobiology of T cell vaccination (17).

\section{Acknowledgments}

Research was supported by NIH grants AI39630 and AI39675 and National Multiple Sclerosis Society grant RG2938A (to H. Jiang), and by NIH grant U19 AI/46132 (to L. Chess).

Address correspondence to: Leonard Chess, Department of Medicine and Pathology, Rheumatology Division, Columbia University College of Physicians and Surgeons, 630 West 168th Street, PH8E, Suite 101, New York, New York 10032, USA. Phone: (212) 3059986; Fax: (212) 305-4943; E-mail: LC19@Columbia.edu.
9. Jiang, H., et al. 2003. Regulatory CD8+ T cells finetune the myelin basic protein-reactive $T$ cell receptor $\mathrm{V}$ beta repertoire during experimental autoimmune encephalomyelitis. Proc. Natl. Acad. Sci. U. S. A. 100:8378-8383.

10. Fehérvari, Z., and Sakaguchi, S. 2004. CD4 ${ }^{+}$Tregs and immune control. J. Clin. Invest. 114:1209-1217. doi:10.1172/200423395.

11. O'Garra, A., Vieira, P.L., Vieira, P., and Goldfeld, A.E. 2004. IL-10 producing and naturally occurring Tregs: limiting collateral damage. J. Clin. Invest. In press. doi:10.1172/JCI200423215

12. Walsh, P.T., Taylor, D.K., and Turka, L.A. 2004. Tregs and transplantation tolerance. J. Clin. Invest. In press. doi:10.1172/200423238.

13. Sarantopoulos, S., Lu, L., and Cantor, H. 2004. Qa-1 restriction of $\mathrm{CD}^{+}$suppressor T cells. J. Clin. Invest. 114:1218-1221. doi:10.1172/JCI200423152.

14. Kumar, V. 2004. Homeostatic control of immunity by TCR peptide-specific Tregs. J. Clin. Invest. 114:1222-1226. doi:10.1172/JCI200423166.

15. Godfrey, D.I., and Kronenberg, M. 2004. Going both ways: immune regulation via CD1d-dependent NKT cells. J. Clin. Invest. In press. doi:10.1172/ JCI200423594.

16. Robinson, D.S., Larché, M., and Durham, S.R. 2004. Tregs and allergic disease. J. Clin. Invest. In press. doi:10.1172/JCI200423595.
17. Cohen, I.R., Quintana, F.J., and Mimran, A. 2004 Tregs in $\mathrm{T}$ cell vaccination: exploring the regulation of regulation. J. Clin. Invest. 114:1227-1232. doi:10.1172/JCI200423396

18. Mueller, D.L., Jenkins, M.K., and Schwartz, R.H. 1989. Clonal expansion versus functional clonal inactivation: a costimulatory signaling pathway determines the outcome of $\mathrm{T}$ cell antigen receptor occupancy [review]. Ananu. Rev. Immunol. 7:445-480.

19. Janeway, C., Jr., and Bottomly, K. 1994. Signals and signs for lymphocyte responses [review]. Cell. 76:275-285.

20. Lenschow, D.J., Walunas, T.L., and Bluestone, J.A. 1996. CD28/B7 system of T cell costimulation. Annu. Rev. Immunol. 14:233-258.

21. Savage, P.A., Boniface, J.J., and Davis, M.M. 1999. A kinetic basis for $\mathrm{T}$ cell receptor repertoire selection during an immune response. Immunity. 10:485-492.

22. Davis, M.M., et al. 1998. Ligand recognition by alpha beta T cell receptors. Annu. Rev. Immunol. 16:523-544.

23. Lenardo, M., et al. 1999. Mature T lymphocyte apoptosis--immune regulation in a dynamic and unpredictable antigenic environment. Annu. Rev. Immunol. 17:221-253.

24. Lederman, S., et al. 1992. Identification of a novel surface protein on activated CD $4+\mathrm{T}$ cells that 
induces contact-dependent B cell differentiation (help). J. Exp. Med. 175:1091-1101.

25. Foy, T.M., Aruffo, A., Bajorath, J., Buhlmann, J.E., and Noelle, R.J. 1996. Immune regulation by CD40 and its ligand GP39 [review]. Annu. Rev. Immunol. 14:591-617.

26. Chess, L. 2000. Blockade of the CD40L/CD40 pathway. In Therapeutic Immunology. 2nd edition. K.F. Austen, S.J. Burakoff, F.S. Rosen, and T.B. Strom, editors. Blackwell Science, Inc. Cambridge, Massachusetts, USA. 441-456.

27. Caux, C., et al. 1994. Activation of human dendritic cells through CD40 cross-linking. J. Exp. Med. 180:1263-1272.

28. Klaus, S.J., et al. 1994. Costimulation through CD28 enhances $T$ cell-dependent B cell activation via CD40-CD40L interaction. J. Immunol. 152:5643-5652.

29. Durie, F.H., Foy, T.M., Masters, S.R., Laman, J.D., and Noelle, R.J. 1994. The role of CD40 in the regulation of humoral and cell-mediated immunity [review]. Immunol. Today. 15:406-411.

30. Koulova, L., Clark, E.A., Shu, G., and Dupont, B. 1991. The CD28 ligand B7/BB1 provides costimulatory signal for alloactivation of CD4+ T cells. J. Exp. Med. 173:759-762

31. Coffman, R.L., and Mosmann, T.R. 1991. CD4+ Tcell subsets: regulation of differentiation and function [review]. Res. Immunol. 142:7-9.

32. Mosmann, T.R., Cherwinski, H., Bond, M.W., Giedlin, M.A., and Coffman, R.L. 1986. Two types of murine helper T cell clone. I. Definition according to profiles of lymphokine activities and secreted proteins. J. Immunol. 136:2348-2357.

33. Mosmann, T.R., and Coffman, R.L. 1989. TH1 and TH2 cells: different patterns of lymphokine secretion lead to different functional properties. Annu. Rev. Immunol. 7:145-173.

34. Fitch, F.W., McKisic, M.D., Lancki, D.W., and Gajewski, T.F. 1993. Differential regulation of murine T lymphocyte subsets. Annu. Rev. Immunol. 11:29-48.

35. Seder, R.A., and Paul, W.E. 1994. Acquisition of lymphokine-producing phenotype by CD4+ T cells. Annu. Rev. Immunol. 12:635-673.

36. Groux, H., et al. 1997. A CD4+ T-cell subset inhibits antigen-specific T-cell responses and prevents colitis. Nature. 389:737-742.

37. Levings, M.K., and Roncarolo, M.G. 2000. T-regulatory 1 cells: a novel subset of CD4 T cells with immunoregulatory properties. J. Allergy Clin. Immunol. 106:S109-S112.

38. Roncarolo, M.G., and Levings, M.K. 2000. The role of different subsets of $\mathrm{T}$ regulatory cells in controlling autoimmunity. Curr. Opin. Immunol. 12:676-683.

39. Charlton, B., and Lafferty, K.J. 1995. The Th1/Th2 balance in autoimmunity. Curr. Opin. Immunol. 7:793-798.

40. Del Prete, G. 1998. The concept of type-1 and type2 helper T cells and their cytokines in humans. Int. Rev. Immunol. 16:427-455.

41. O'Garra, A., and Vieira, P. 2004. Regulatory T cells and mechanisms of immune system control. Nat. Med. 10:801-805.

42. Gershon, R.K., and Kondo, K. 1970. Cell interactions in the induction of tolerance: the role of thymic lymphocytes. Immunology. 18:723-737.

43. Gershon, R.K., and Kondo, K. 1971. Infectious immunological tolerance. Immunology. 21:903-914.

44. Green, D.R., Flood, P.M., and Gershon, R.K. 1983. Immunoregulatory T-cell pathways. Annu. Rev. Immunol. 1:439-463.

45. Bloom, B.R., Salgame, P., and Diamond, B. 1992. Revisiting and revising suppressor T cells. Immunol. Today. 13:131-136.

46. Cantor, H., and Boyse, E.A. 1975. Functional subclasses of T lymphocytes bearing different Ly antigens. II. Cooperation between subclasses of $\mathrm{Ly}^{+}$ cells in the generation of killer activity. J. Exp. Med. 141:1390-1399.

47. Cantor, H., and Boyse, E.A. 1975. Functional subclasses of T-lymphocytes bearing different Ly antigens. I. The generation of functionally distinct T-cell subclasses is a differentiative process independent of antigen. J. Exp. Med. 141:1376-1389.

48. Chess, L., and Schlossman, S.F. 1977. Human lymphocyte subpopulations. Adv. Immunol. 25:213-241.

49. Reinherz, E.L., and Schlossman, S.F. 1980. The differentiation and function of human $\mathrm{T}$ lymphocytes. Cell. 19:821-827.

50. Thomas, Y., et al. 1980. Functional analysis of human $\mathrm{T}$ cell subsets defined by monoclonal antibodies. I. Collaborative T-T interactions in the immunoregulation of $\mathrm{B}$ cell differentiation. J. Immunol. 125:2402-2408.

51. Stanton, T.H., et al. 1978. The Qa-1 antigenic system. Relation of Qa-1 phenotypes to lymphocyte sets, mitogen responses, and immune functions. J. Exp. Med. 148:963-973.

52. Eardley, D.D., et al. 1978. Immunoregulatory circuits among T-cell sets. I. T-helper cells induce other T-cell sets to exert feedback inhibition. J. Exp. Med. 147:1106-1115.

53. Shawar, S.M., Vyas, J.M., Rodgers, J.R., and Rich, R.R. 1994. Antigen presentation by major histocompatibility complex class I-B molecules. Annu. Rev. Immunol. 12:839-880.

54. Jiang, H., et al. 1995. Murine CD8+ T cells that specifically delete autologous CD4+ T cells expressing $\mathrm{V}$ beta 8 TCR: a role of the Qa-1 molecule. Immunity. 2:185-194.

55. Jiang, H., et al. 1998. T cell vaccination induces $T$ cell receptor Vbeta-specific Qa-1- restricted regulatory CD8(+) T cells. Proc. Natl. Acad. Sci. U. S. A. 95:4533-4537.

56. Hu, D., et al. 2004. Analysis of regulatory CD8 T cells in mice deficient in the Qa-1 class Ib molecule, H2-T23. Nat. Immunol. 5:516-523.

57. Moller, G. 1988. Do suppressor T cells exist? Scand. J. Immunol. 27:247-250.

58. Janeway, C.A., Jr. 1988. Do suppressor T cells exist? A reply. Scand. J. Immunol. 27:621-623.

59. Jiang, H., Zhang, S.I., and Pernis, B. 1992. Role of CD8 $+\mathrm{T}$ cells in murine experimental allergic encephalomyelitis. Science. 256:1213-1215.

60. Koh, D.-R., et al. 1992. Less mortality but more relapses in experimental allergic encephalomyelitis in CD8-/- mice. Science. 256:1210-1213.

61. Jiang, H., Braunstein, N.S., Yu, B., Winchester, R., and Chess, L. 2001. CD8+ T cells control the TH phenotype of MBP-reactive CD4+ T cells in EAE mice. Proc. Natl. Acad. Sci. U. S. A. 98:6301-6306.

62. Panoutsakopoulou, V., et al. 2004. Suppression of autoimmune disease after vaccination with autoreactive $T$ cells that express $Q \mathrm{a}-1$ peptide complexes. J. Clin. Invest. 113:1218-1224. doi:10.1172/ JCI200420772.

63. Aldrich, C.J., et al. 1994. Identification of a Tapdependent leader peptide recognized by alloreactive $\mathrm{T}$ cells specific for a class $\mathrm{Ib}$ antigen. Cell. 79:649-658.

64. Jiang, S., et al. 1998. Induction of MHC-class I restricted human suppressor $\mathrm{T}$ cells by peptide priming in vitro. Hum. Immunol. 59:690-699.

65. Chang, C.C., et al. 2002. Tolerization of dendritic cells by $\mathrm{T}(\mathrm{S})$ cells: the crucial role of inhibitory receptors ILT3 and ILT4. Nat. Immunol. 3:237-243.

66. Najafian, N., et al. 2003. Regulatory functions of CD8+CD28- $T$ cells in an autoimmune disease model. J. Clin. Invest. 112:1037-1048. doi:10.1172/ JCI200317935.

67. Jiang, H., and Chess, L. 2000. The specific regulation of immune responses by CD8+ T cells restricted by the MHC class IB molecule, QA-1. Annu. Rev. Immunol. 18:185-216.

68. Li, J., Goldstein, I., Glickman-Nir, E., Jiang, H., and
Chess, L. 2001. Induction of TCR Vbeta-specific CD8+ CTLs by TCR Vbeta-derived peptides bound to HLA-E. J. Immunol. 167:3800-3808.

69. Cantor, H., Shen, F.W., and Boyse, E.A. 1976. Separation of helper $\mathrm{T}$ cells from suppressor $\mathrm{T}$ cells expressing different Ly components. II. Activation by antigen: after immunization, antigen-specific suppressor and helper activities are mediated by distinct T-cell subclasses. J. Exp. Med. 143:1391-1340.

70. Sakaguchi, S., Fukuma, K., Kuribayashi, K., and Masuda, T. 1985. Organ-specific autoimmune diseases induced in mice by elimination of $\mathrm{T}$ cell subset. I. Evidence for the active participation of $\mathrm{T}$ cells in natural self-tolerance; deficit of a $\mathrm{T}$ cell subset as a possible cause of autoimmune disease. J. Exp. Med. 161:72-87.

71. Sakaguchi, S., Sakaguchi, N., Asano, M., Itoh, M., and Toda, M. 1995. Immunologic self-tolerance maintained by activated T cells expressing IL-2 receptor alpha-chains (CD25). Breakdown of a single mechanism of self-tolerance causes various autoimmune diseases. J. Immunol. 155:1151-1164.

72. Shevach, E.M. 2000. Regulatory T cells in autoimmunity. Annu. Rev. Immunol. 18:423-449.

73. Thomas, Y., et al. 1981. Functional analysis of human $\mathrm{T}$ cell subsets defined by monoclonal antibodies. IV. Induction of suppressor cells within the OKT4+ population. J. Exp. Med. 154:459-467.

74. Thomas, Y., et al. 1982. Functional analysis of human $T$ cell subsets defined by monoclonal antibodies. V. Suppressor cells within the activated OKT4+ population belong to a distinct subset. J. Immunol. 128:1386-1390.

75. Shevach, E.M. 2001. Certified professionals: CD4(+)CD25(+) suppressor T cells. J. Exp. Med. 193: F41-F46.

76. Sakaguchi, S. 2000. Regulatory T cells: key controllers of immunologic self-tolerance. Cell. 101:455-458.

77. Apostolou, I., Sarukhan, A., Klein, L., and von Boehmer, H. 2002. Origin of regulatory T cells with known specificity for antigen. Nat. Immunol. 3:756-763.

78. Curotto de Lafaille, M.A., and Lafaille, J.J. 2002. $\mathrm{CD} 4(+)$ regulatory $\mathrm{T}$ cells in autoimmunity and allergy. Curr. Opin. Immunol. 14:771-778.

79. Lafaille, J.J., Nagashima, K., Katsuki, M., and Tonegawa, S. 1994. High incidence of spontaneous autoimmune encephalomyelitis in immunodeficient anti-myelin basic protein $\mathrm{T}$ cell receptor transgenic mice. Cell. 78:399-408.

80. Lafaille, J.J. 1998. The role of helper T cell subsets in autoimmune diseases. Cytokine Growth Factor Rev. 9:139-151.

81. Van de Keere, F., and Tonegawa, S. 1998. CD4(+) $\mathrm{T}$ cells prevent spontaneous experimental autoimmune encephalomyelitis in anti-myelin basic protein T cell receptor transgenic mice. J. Exp. Med. 188:1875-1882.

82. Furtado, G.C., et al. 2001. Regulatory T cells in spontaneous autoimmune encephalomyelitis. Immunol. Rev. 182:122-134.

83. Shevach, E.M. 2002. CD4+ CD25+ suppressor T cells: more questions than answers. Nat. Rev. Immunol. 2:389-400.

84. Piccirillo, C.A., and Thornton, A.M. 2004. Cornerstone of peripheral tolerance: naturally occurring CD4+CD25+ regulatory $\mathrm{T}$ cells. Trends Immunol. 25:374-380.

85. Takahashi, T., et al. 2000. Immunologic self-tolerance maintained by $\mathrm{CD} 25(+) \mathrm{CD} 4(+)$ regulatory $\mathrm{T}$ cells constitutively expressing cytotoxic T lymphocyte-associated antigen 4. J. Exp. Med. 192:303-310.

86. Salomon, B., et al. 2000. B7/CD28 costimulation is essential for the homeostasis of the CD4+CD25+ immunoregulatory $\mathrm{T}$ cells that control autoimmune diabetes. Immunity. 12:431-440.

87. Shevach, E.M., McHugh, R.S., Piccirillo, C.A., and Thornton, A.M. 2001. Control of T-cell activation 
by CD4+ CD25+ suppressor T cells. Immunol. Rev. 182:58-67.

88. Gorelik, L., and Flavell, R.A. 2000. Abrogation of TGFbeta signaling in $\mathrm{T}$ cells leads to spontaneous $\mathrm{T}$ cell differentiation and autoimmune disease. Immunity. 12:171-181.

89. Seddon, B., and Mason, D. 1999. Regulatory T cells in the control of autoimmunity: the essential role of transforming growth factor beta and interleukin 4 in the prevention of autoimmune thyroiditis in rats by peripheral CD4(+)CD45RC- cells and CD4(+)CD8(-) thymocytes. J. Exp. Med. 189:279-288.

90. Zhai, Y., and Kupiec-Weglinski, J.W. 1999. What is the role of regulatory $\mathrm{T}$ cells in transplantation tolerance? Curr. Opin. Immunol. 11:497-503.

91. Bennett, C.L., et al. 2001. The immune dysregulation, polyendocrinopathy, enteropathy, $\mathrm{X}$-linked syndrome (IPEX) is caused by mutations of FOXP3. Nat. Genet. 27:20-21.

92. Brunkow, M.E., et al. 2001. Disruption of a new forkhead/winged-helix protein, scurfin, results in the fatal lymphoproliferative disorder of the scurfy mouse. Nat. Genet. 27:68-73.

93. Wildin, R.S., et al. 2001. X-linked neonatal diabetes mellitus, enteropathy and endocrinopathy syndrome is the human equivalent of mouse scurfy. Nat. Genet. 27:18-20.

94. Fontenot, J.D., Gavin, M.A., and Rudensky, A.Y. 2003. Foxp3 programs the development and function of CD $4+\mathrm{CD} 25+$ regulatory T cells. Nat. Immunol. 4:330-336.

95. Walker, M.R., et al. 2003. Induction of FoxP3 and acquisition of $\mathrm{T}$ regulatory activity by stimulated human CD4+CD25- T cells. J. Clin. Invest. 112:1437-1443. doi:10.1172/JCI200319441.

96. Chen, W., et al. 2003. Conversion of peripheral CD4+CD25- naive $\mathrm{T}$ cells to CD4+CD25+ regulatory $\mathrm{T}$ cells by TGF-beta induction of transcription factor Foxp3. J. Exp. Med. 198:1875-1886.

97. Cosmi, L., et al. 2003. Human CD8+CD25+ thymocytes share phenotypic and functional features with CD4+CD25+ regulatory thymocytes. Blood. 102:4107-4114.

98. Manavalan, J.S., et al. 2004. Alloantigen specific CD8+CD28- FOXP3 + T suppressor cells induce ILT3+ ILT4+ tolerogenic endothelial cells, inhibiting alloreactivity. Int. Immunol. 16:1055-1068.
99. Thornton, A.M., and Shevach, E.M. 2000. Suppressor effector function of CD $4+C D 25+$ immunoregulatory $\mathrm{T}$ cells is antigen nonspecific. J. Immunol. 164:183-190.

100.Piccirillo, C.A., and Shevach, E.M. 2001. Cutting edge: control of CD8+ $\mathrm{T}$ cell activation by CD4+CD25+ immunoregulatory cells. J. Immunol. 167:1137-1140.

101. Sakaguchi, S. 2003. Control of immune responses by naturally arising CD4+ regulatory $\mathrm{T}$ cells that express toll-like receptors. J. Exp. Med. 197:397-401.

102.Bendelac, A. 1995. Mouse NK1+ T cells. Curr. Opin. Immunol. 7:367-374.

103.Bendelac, A., Rivera, M.N., Park, S.H., and Roark, J.H. 1997. Mouse CD1-specific NK1 T cells: development, specificity, and function. Annu. Rev. Immunol. 15:535-562.

104.Exley, M., Garcia, J., Balk, S.P., and Porcelli, S. 1997. Requirements for CD1d recognition by human invariant Valpha24+ CD4-CD8- T cells. J. Exp. Med. 186:109-120.

105.Lee, P.T., Benlagha, K., Teyton, L., and Bendelac, A. 2002. Distinct functional lineages of human V(alpha)24 natural killer T cells. J. Exp. Med. 195:637-641.

106.Eberl, G., et al. 1999. Tissue-specific segregation of CD1d-dependent and CD1d-independent NK T cells. J. Immunol. 162:6410-6419.

107. Cui, J., et al. 1997. Requirement for Valpha14 NKT cells in IL-12-mediated rejection of tumors. Science. 278:1623-1626.

108.Gombert, J.M., et al. 1996. Early quantitative and functional deficiency of NK1+-like thymocytes in the NOD mouse. Eur. J. Immunol. 26:2989-2998.

109.Godfrey, D.I., Hammond, K.J., Poulton, L.D., Smyth, M.J., and Baxter, A.G. 2000. NKT cells: facts, functions and fallacies. Immunol. Today. 21:573-583.

110. Bendelac, A., et al. 1995. CD1 recognition by mouse NK1+ T lymphocytes. Science. 268:863-865.

111.Sharif, S., Arreaza, G.A., Zucker, P., and Delovitch, T.L. 2002. Regulatory natural killer T cells protect against spontaneous and recurrent type 1 diabetes. Ann. N. Y. Acad. Sci. 958:77-88.

112.D'Orazio, T.J., and Niederkorn, J.Y. 1998. A novel role for TGF-beta and IL-10 in the induction of immune privilege. J. Immunol. 160:2089-2098.
113.Furlan, R., et al. 2003. Activation of invariant NKT cells by alphaGalCer administration protects mice from MOG35-55-induced EAE: critical roles for administration route and IFN-gamma. Eur. J. Immunol. 33:1830-1838.

114.Singh, A.K., et al. 2001. Natural killer T cell activation protects mice against experimental autoimmune encephalomyelitis. J. Exp. Med. 194:1801-1811.

115.Baxter, A.G., Kinder, S.J., Hammond, K.J., Scollay, R., and Godfrey, D.I. 1997. Association between alphabetaTCR+CD4-CD8- T-cell deficiency and IDDM in NOD/Lt mice. Diabetes. 46:572-582.

116.Hammond, K.J., et al. 1998. Alpha/beta-T cell receptor (TCR)+CD4-CD8- (NKT) thymocytes prevent insulin-dependent diabetes mellitus in nonobese diabetic (NOD)/Lt mice by the influence of interleukin (IL)-4 and/or IL-10. J. Exp. Med. 187:1047-1056

117. Sharif, S., et al. 2001. Activation of natural killer $\mathrm{T}$ cells by alpha-galactosylceramide treatment prevents the onset and recurrence of autoimmune type 1 diabetes. Nat. Med. 7:1057-1062.

118.Falcone, M., Yeung, B., Tucker, L., Rodriguez, E., and Sarvetnick, N. 1999. A defect in interleukin 12 -induced activation and interferon gamma secretion of peripheral natural killer T cells in nonobese diabetic mice suggests new pathogenic mechanisms for insulin-dependent diabetes mellitus. J. Exp. Med. 190:963-972.

119. Frey, A.B., and Rao, T.D. 1999. NKT cell cytokine imbalance in murine diabetes mellitus. Autoimmunity. 29:201-214.

120. Wilson, S.B., et al. 1998. Extreme Th1 bias of invariant Valpha24JalphaQ $\mathrm{T}$ cells in type 1 diabetes. Nature. 391:177-181.

121.Lee, P.T., et al. 2002. Testing the NKT cell hypothesis of human IDDM pathogenesis. J. Clin. Invest. 110:793-800. doi:10.1172/JCI200215832.

122.Bendelac, A., and Fearon, D.T. 1997. Innate pathways that control acquired immunity. Curr. Opin. Immunol. 9:1-3.

123.Wilbanks, G.A., and Streilein, J.W. 1990. Distinctive humoral immune responses following anterior chamber and intravenous administration of soluble antigen. Evidence for active suppression of IgG2secreting B lymphocytes. Immunology. 71:566-572. 